\title{
Aplication of Mental Nursing Care on Mrs. P with Perceptual Sensory Disorders: Auditory Hallucinations
}

\author{
Elis Melina Br Manullang \\ emelinamanullang@gmail.com
}

\section{BAB 1 \\ PENDAHULUAN}

\subsection{Latar Belakang}

Orang dengan gangguan jiwa (ODGJ), adalah orang yang mengalamai gangguan dalam pikiran, perilaku, dan perasaan yang termanifestasi dalam bentuk sekumpulan gejala dan/atau perubahan yang bermakna, serta dapat menimbulkan penderitaan dan hambatan dalam menjalankan kehidupan (Kemenkes RI, 2019). Skizofrenia merupakan salah satu penyakit neurologis yang menjadi masalah kesehatan utama di negara - negara berkembang, dan merupakan salah satu dari empat masalah kesehatan utama. Gangguan jiwa (mental disorder) secara langsung tidak dianggap sebagai gangguan yang dapat mengakibatkan kematian, namun setiap individu yang mengalami gangguan tersebut sering kali dianggap sebagai penghambat dikarenakan mereka sudah tidak dapat melakukan sesuatu secara efisien dan produktif (Hidayah, 2015).

Skizofrenia adalah suatu gangguan jiwa berat yang ditandai dengan penurunan atau ketidakmampuan berkomunikasi, gangguan realitas (halusinasi dan waham), afek tidak wajar atau tumpul, gangguan kognitif (tidak mampu berfikir abstrak) serta mengalami kesukaran melakukan aktivitas seharihari. Gejala-gejala skizofrenia adalah sebagai berikut: gejala positif (waham, halusinasi, perubahan arus pikir, perubahan perilaku) dan gejala negatif (sikap masa bodoh (apatis), pembicaraan terhenti tiba-tiba (blocking), menarik diri dari pergaulan sosial (isolasi sosial), menurunnya kinerja atau aktivitas sosial sehari-hari (Putri, 2017). Gejala positif dari skizofrenia adalah halusinasi. Hal 
inilah yang membuat perlu bantuan keluarga untuk merawat dan memberikan perhatian khusus pada pasien skizofrenia (Pardede \& Siregar, 2016).

Menurut World Health Organization (WHO, 2019) Skizofrenia merupakan suatu gangguan jiwa berat yang bersifat berat dan kronis yang menyerang 20 juta orang di seluruh dunia. Skizofrenia merupakan penyakit kronis, parah, dan melumpuhkan, gangguan otak yang di tandai dengan pikiran kacau, waham, delusi, halusinasi, dan perilaku aneh atau katatonik (Pardede \& Laia, 2020). Secara global kontributor terbesar beban penyakit (DALYs) dari YLDs (tahun hilang akibat kesakitan atau kecacatan), maka persentase kontributor lebih besar pada gangguan mental (14,4\%). Kondisi untuk Asia Tenggara tidak berbeda dengan kondisi global dimana penyebab penyakit kematian terbesar adalah penyakit kardiovaskuler (31,5\%), tapi dilihat dari YLDs kontributor lebih besar pada gangguan mental (13,5\%) (Kemenkes RI, 2019).

Salah satu gejala yang paling sering muncul pada skizofrenia adalah munculnya halusinasi yaitu sekitar $70 \%$. Halusinasi yang sering dialami pasien gangguan jiwa adalah halusinasi pendengaran, 20\% mengalami halusinasi penglihatan dan $10 \%$ adalah halusinasi penghidu, pengacapan dan perabaan. Berdasarkan data tersebut diketahui bahwa jenis halusinasi yang paling banyak diderita oleh pasien dengan skizofren adalah halusinasi pendengaran (Hidayah, 2015). Menurut Pardede, Silitonga \& Laia (2020) halusinasi merupakan keadaan seseorang yang mengalami perubahan pola dan jumlah rangsangan yang dimulai secara internal atau eksternal di sekitarnya dengan pengurangan, pembesaran, distorsi, atau ketidaknormalan respon terhadap setiap rangsangan.

Halusinasi didefinisikan sebagai terganggunya persepsi seseorang, dimana tidak terdapat stimulus. Tipe halusinasi yang paling sering adalah halusinasi pendengaran. Halusinasi pendengaran dapat berupa bunyi mendenging atau suara bising yang tidak mempunyai arti, tetapi lebih sering terdengar sebagai sebuah kata atau kalimat yang bermakna (Sumartyawati, 2019). Halusinasi 
merupakan keadaan seseorang mengalami perubahan dalam pola dan jumlah stimulasi yang diprakarsai secara internal atau eksternal disekitar dengan pengurangan, berlebihan, distorsi, atau kelainan berespon terhadap setiap stimulus (Pardede, Keliat \& Yulia 2015).

Halusinasi benar-benar nyata dirasakan oleh klien yang mengalaminya, seperti mimpi saat tidur. Klien mungkin tidak punya cara untuk menentukan persepsi tersebut nyata, sama halnya seseorang seperti seseorang yang mendengarkan siaran ramalan cuaca dan tidak lagi meragukan orang yang berbicara tentang cuaca tersebut. Ketidakmampuan untuk mempersepsikan stimulus secara real dapat menyulitkan kehidupan klien. Karenanya halusinasi menjadi prioritas untuk segera diatasi (Putri, 2017).

Survei awal pada pembuatan asuhan keperawatan pada skizofrenia ini dilakukan di Yayasan Pemenang Jiwa Sumatera dengan jumlah pasien 70 orang tetapi yang menjadi subjek di dalam pembuatan asuhan keperawatan ini berjumlah 1 orang yang mengalami masalah halusinasi pendengaran dengan inisial nama Ny. P. Penyebabnya Ny. P di jadikan sebagai subjek dikarenakan pasien belum bisa mengatasi halusinasinya selain meminum obat. Maka tujuan asuhan keperawatan yang akan di lakukan ialah untuk mengajarkan standar pelaksanaan masalah halusinasi pendengaran pada saat $\mathrm{Ny}$. P mengalami halusinasi.

\subsection{Rumusan Masalah}

Berdasarkan masalah yang telah di paparkan pada latar belakang maka rumusan masalah dalam askep ini yaitu Asuhan Keperawatan Dengan Masalah Halusinasi Pendengaran Pada Ny. P di Yasasan Pemenang Jiwa Sumatera. 


\subsection{Tujuan}

\subsubsection{Tujuan Umum}

Mahasiswa mampu memberikan asuhan keperawatan secara holistik dan komprehensif kepada Ny. P dengan masalah halusinasi pendengaran di Yayasan Pemenang Jiwa Sumatera.

\subsubsection{Tujuan Khusus}

a. Mahasiswa mampu memahami pengertian, tanda dan gejala, etiologi, penatalaksanaan medis dan keperawatan gangguan persepsi sensori : halusinasi pendengaran.

b. Mahasiswa mampu melakukan pengkajian pada Ny. P dengan gangguan persepsi sensori : halusinasi pendengaran.

c. Mahasiswa mampu melakukan menegakkan diagnosa pada Ny. P dengan gangguan persepsi sensori : halusinasi pendengaran.

d. Mahasiswa mampu melakukan menetapkan perencanaan pada $\mathrm{Ny}$. $\mathrm{P}$ dengan gangguan persepsi sensori : halusinasi pendengaran.

e. Mahasiswa mampu melakukan implementasi pada Ny. P dengan gangguan persepsi sensori : halusinasi pendengaran.

f. Mahasiswa mampu melakukan evaluasi pada Ny. P dengan gangguan persepsi sensori : halusinasi pendengaran.

g. Mahasiswa mampu mendokumentasikan asuhan keperawatan yang diberikan pada Ny. P dengan gangguan persepsi sensori : halusinasi pendengaran.

\subsection{Manfaat}

1. Responden

Diharapkan tindakan yang telah di ajakarkan dapat di terapkan secara mandiri untuk mengontrol emosi dan untuk mendukung kelangsungan kesehatan pasien.

2. Yayasan Pemenang Jiwa Sumatera.

Diharapkan dapat menjadi acuan dalam menanganin atau dalam memberikan pelayanan kepada pasien dengan gangguan jiwa dengan perilaku kekerasan di Yayasan Pemenang Jiwa Sumatera. 


\section{BAB 2 \\ TINJAUAN TEORITIS}

\subsection{Konsep Halusianasi}

\subsubsection{Defenisi}

Halusinasi adalah suatu keadaan dimana seseorang mengalami perubahan dalam jumlah dan pola dari stimulus yang datang (diprakarsai) dari internal dan eksternal disertai dengan respon menurun atau dilebih-lebihkan atau kerusakan respon pada rangsangan ini (Sutinah, 2020). Halusinasi dapat menghilangkan kontrol diri individu sehingga dapat membahayakan diri sendiri maupun orang lain, ataupun merusak lingkungan. Sebagaimana klien halusinasi fase ke 4, dimana klien mengalami panik dan perilakunya sudah dikendalikan oleh halusinasinya, klien benar-benar kehilangan kontrol dirinya sehingga menimbulkan perilaku kekerasan (Sulianingsih, 2019).

Halusinasi yang dialami oleh individu dapat disebabkan melalui faktor presdisposisi dan presipitasi. Faktor predisposisi terdiri dari faktor biologis yang berhubungan dengan perkembangan sistem saraf yang tidak normal, faktor psikologis seperti pola asuh orang tua, kondisi keluarga dan lingkungan, faktor sosial budaya seperti kondisi ekonomi, konflik sosial, serta kehidupan yang terisolasi disertai stres. Sedangkan faktor lainnya yaitu presipitasi yakni faktor biologi yang terkait dalam gangguan komunikasi dan putaran balik otak yang mengatur proses informasi, faktor lingkungan yang mana terjadi tingkat stresor lingkungan di luar batas toleransi individu, koping yang dapat menentukan seseorang dalam mentoleransi stresor. Klien dengan halusinasi yang telah dikendalikan oleh halusinasinya akan melakukan perilaku yang membahayakan dirinya, orang lain, dan juga lingkungan (Aldam \& Wardani, 2019). 


\subsubsection{Etiologi}

Faktor predisposisi klien halusinasi menurut (Oktiviani, 2020) :

1. Faktor Predisposisi

a. Faktor perkembangan

Tugas perkembangan klien terganggu misalnya rendahnya kontrol dan kehangatan keluarga menyebabkan klien tidak mampu mandiri sejak kecil, mudah frustasi, hilang percaya diri.

b. Faktor sosiokultural

Seseorang yang merasa tidak diterima dilingkungan sejak bayi akan merasa disingkirkan, kesepian, dan tidak percaya pada lingkungan.

c. Biologis

Faktor biologis Mempunyai pengaruh terhadap terjadinya gangguan jiwa. Adanya stress yang berlebihan dialami seseorang maka didalam tubuh akan dihasilkan suatu zat yang dapat bersifat halusinogen neurokimia.Akibat stress berkepanjangan menyebabkan teraktivasinya neurotransmitter otak.

d. Psikologis

Tipe kepribadian lemah dan tidak bertanggung jawab mudah terjerumus pada penyalahgunaan zat adikitif. Hal ini berpengaruh pada ketidakmampuan klien dalam mengambil keputusan yang tepat demi masa depannya, klien lebih memilih kesenangan sesaat dan lari dari alam nyata menuju alam khayal.

e. Sosial Budaya

Meliputi klien mengalami interaksi sosial dalam fase awal dan comforting, klien meganggap bahwa hidup bersosialisasi di alam nyata sangat membahayakan. Klien asyik dengan Halusinasinya, seolah-olah ia merupakan tempat untuk 
memenuhi kebutuhan akan interaksi sosial, kontrol diri dan harga diri yang tidak didapatkan dakam dunia nyata.

2. Faktor Presipitasi

Faktor presipitasi merupakan stimulus yang dipersepsikan oleh individu sebagai tantangan, ancaman, atau tuntutan yang memerlukan energi ekstra untuk menghadapinya. Seperti adanya rangsangan dari lingkungan, misalnya partisipasi klien dalam kelompok, terlalu lama tidak diajak komunikasi, objek yang ada di lingkungan dan juga suasana sepi atau terisolasi, sering menjadi pencetus terjadinya halusinasi. Hal tersebut dapat meningkatkan stress dan kecemasan yang merangsang tubuh mengeluarkan zat halusinogenik.

\subsubsection{Tanda dan Gejala}

Klien dengan gangguan persepsi sensori halusinasi dapat memperlihatkan berbagai tanda dan gejala yang bisa diamati melalui perilaku mereka sehari hari, hal tersebut dapat berupa (Wulandari, 2018) :

1. Tidak dapat memusatkan perhatian/kurangnya konsentrasi

2. Selalu berubah respon dari rangsangan

3. Gelisah

4. Ketakutan

5. Wajah tegang

6. Perubahan ssnsori akut

7. Mudah tersinggung

8. Disorientasi waktu, tempat, dan orang

9. Ketiakmampuan dalam memecahkan masalah

10. Perubahan pola perilaku

11. Sikap curiga dan bermusuhan

12. Menyalahkan diri sendiri/orang lain

13. Berbicara dan tertawa sendiri

14. Mengatakan atau mendengar sesuatu 
15. Menarik diri

16. Mondar mandir

17. Mengganggu lingkungan sekitar

\subsubsection{Rentang Respon Halusinasi}

Halusinasi adalah salah satu gejala gangguan sensori persepsi yang dialami oleh pasien gangguan jiwa. Pasien merasakan sensasi berupa suara, pengelihatan, pengecapan, perabaan, atau penghiduan tanpa stimulus yang nyata. Rentang respon halusinasi (Zelika \& Dermawan, 2015) :

Respon Adaptif Respon Mal Adaptif

\begin{tabular}{|l|l|l|}
\hline \multicolumn{2}{|c|}{ - Pikiran logis } & - Distorsi \\
- Persepsi akurat & pikiran/pikiran & - Waham \\
- Emosi konsisten & kadang & - Halusinasi \\
dengan & menyimpang & - Sulit berespon \\
pengalaman & - Ilusi & disorganisasi \\
- Perilaku sesuai & - Reaksi emosional & - Isolasi sosial \\
- Berhubungan & berlebihan/kurang & \\
sosial & - Perilaku & \\
& aneh/tidak biasa & \\
\hline & - Menarik diri & \\
\hline
\end{tabular}

Proses terjadinya halusinasi (Wulandari, 2018) :

1. Respon adaptif adalah respon yang dapat diterima oleh norma sosial, dan budaya yang berlaku. Dengan kata lain individu dapat mencari solusi dalam setiap masalah yang dihadapi.

a. Pikiran logis adalah pandangan yang mengarah pada kenyataan.

b. Persepsi akurat adalah pandanagan yang tepat pada kenyataan.

c. Emosi konsisten dengan pengalaman yaitu perasaan yang timbul dari pengalaman ahli. 
d. Perilaku sosial adalah skap dan tingkah laku yang masih dalam batas kewajaran.

e. Hubungan sosial adalah proses suatu interaksi dengan orang lain dan lingkungan.

2. Respon psikososial meliputi

a. Proses pikian terganggu adalah proses yang menimbulkan gangguan.

b. Ilusi adalah gangguan interpretasi atau penilaian yang salah tentang penerapan yang benar - benar terjadi (objek nyata) karena rangsangan panca indra.

c. Emosi berlebihan atau berkurang.

d. Perilaku tidak biasa adalah sikap dan tingkah laku yang melebihi batas kewajaran.

e. Menarik diri yaitu percobaan untuk menhindari interaksi dengan orang lain.

3. Respon maladaptif adalah respon individu dalam menyelesaikan masalah yang menyimpang dari norma - norma sosial budaya dan lingkungan, adapun respon maladapif meliputi :

a. Waham adalah keyakinanyang secara kokoh diperthankan walaupun tidak diyakini oleh orang lain dan bertentangan dengan kenyataaan.

b. Halusinasi merupakan persepsi sensori yang salah atau persepsi eksternal yang tidak realita (tidak ada).

c. Kerusakan proses emosi adalah sesuatu yang timbul dari hati.

d. Isolasi sosial adalah kondisi kesendirian yang dialami oleh individu dan diterima sebagai ketentuan oleh orang lain dan sebagai sesuatu yang mengancam. 


\subsubsection{Klasifikasi Halusinasi}

Menurut Rossyda (2019), klasifikasi halusinasi dibagi menjadi 5 yaitu sebagai berikut :

\begin{tabular}{|c|c|c|}
\hline Jenis Halusinasi & Data Objektif & Data Subjektif \\
\hline $\begin{array}{l}\text { Halusinasi } \\
\text { Dengar/suara }\end{array}$ & $\begin{array}{l}\text { 1. Bicara atau tertawa } \\
\text { sendiri } \\
\text { 2. Marah-marah tanpa } \\
\text { sebab } \\
\text { 3. Menyedengkan } \\
\text { telinga ke arah } \\
\text { tertentu } \\
\text { 4. Menutup telinga }\end{array}$ & 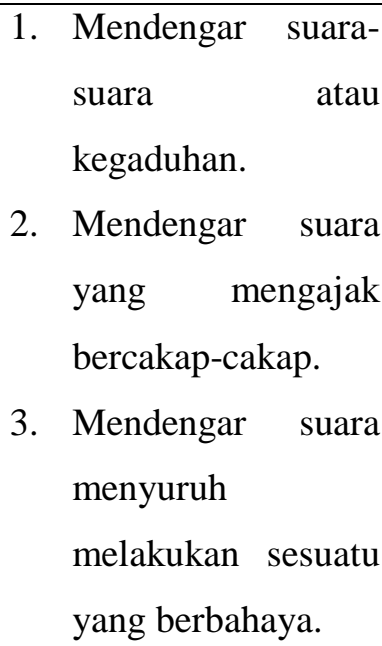 \\
\hline $\begin{array}{l}\text { Halusinasi } \\
\text { Penglihatan }\end{array}$ & $\begin{array}{l}\text { 1. Menunjuk-nunjuk } \\
\text { ke arah tertentu } \\
\text { 2. Ketakutan pada } \\
\text { sesuatu yang tidak } \\
\text { jelas }\end{array}$ & $\begin{array}{l}\text { 1. Melihat bayangan, } \\
\text { sinar, bentuk } \\
\text { geometris, bentuk } \\
\text { kartoon, melihat } \\
\text { hantu atau monster }\end{array}$ \\
\hline $\begin{array}{l}\text { Halusinasi } \\
\text { Penghidu }\end{array}$ & $\begin{array}{l}\text { 1. Menghidu seperti } \\
\text { sedang membaui } \\
\text { bau-bauan tertentu. } \\
\text { 2. Menutup hidung. }\end{array}$ & $\begin{array}{l}\text { 1. Membaui bau- } \\
\text { bauan seperti bau } \\
\text { darah, urin, feses, } \\
\text { kadang-kadang bau } \\
\text { itu menyenangkan. }\end{array}$ \\
\hline $\begin{array}{l}\text { Halusinasi } \\
\text { Pengecapan }\end{array}$ & $\begin{array}{l}\text { 1. Sering meludah } \\
\text { 2. Muntah }\end{array}$ & $\begin{array}{l}\text { 1. Merasakan rasa } \\
\text { seperti darah, urin } \\
\text { atau feses }\end{array}$ \\
\hline $\begin{array}{l}\text { Halusinasi } \\
\text { Perabaan }\end{array}$ & $\begin{array}{l}\text { 1. } \\
\text { permukgaruk-garuk } \\
\text { permuan kulit }\end{array}$ & $\begin{array}{ll}\text { 1. } & \text { Mengatakan ada } \\
\text { serangga } & \text { di } \\
\text { permukaan kulit } \\
\text { 2. } \\
\text { Merasa seperti } \\
\text { tersengat listrik }\end{array}$ \\
\hline
\end{tabular}




\subsubsection{Tahapan Halusinasi}

Halusinasi dapat dibagi menjadi beberapa tahapan, yaitu sebagai berikut (Sejati, 2017) :

\begin{tabular}{|c|c|c|}
\hline Tahapan & Karakteristik & Perilaku \\
\hline $\begin{array}{l}\text { Sleep Disorder : } \\
\text { tahap awal seseorang } \\
\text { sebelum muncul } \\
\text { halusinasi }\end{array}$ & 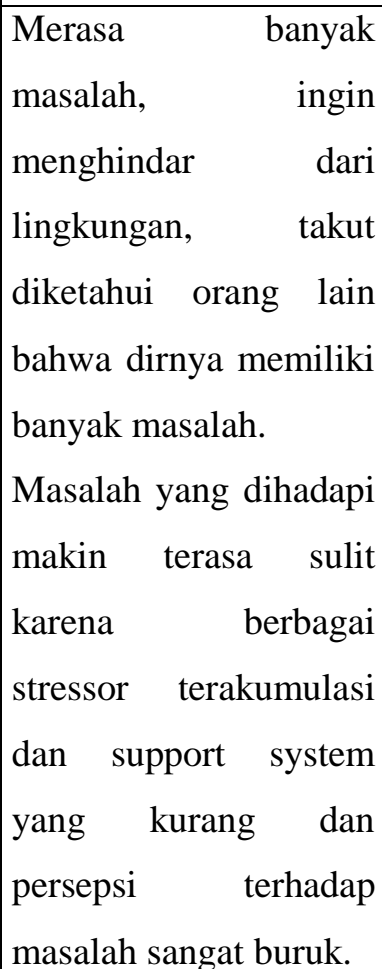 & $\begin{array}{lr}\text { Susah tidur } & \text { dan } \\
\text { berlangsung } & \text { terus } \\
\text { menerus } & \text { sehingga } \\
\text { terbisasa } & \text { menghayal } \\
\text { dan } & \text { menganggap } \\
\text { menghayal } & \text { awal } \\
\text { sebagai } & \text { pemecahan } \\
\text { masalah. } & \end{array}$ \\
\hline $\begin{array}{l}\text { Comforthing : } \\
\text { halusinasi ada pada } \\
\text { tahap menyenangkan } \\
\text { (cemas sedang) }\end{array}$ & 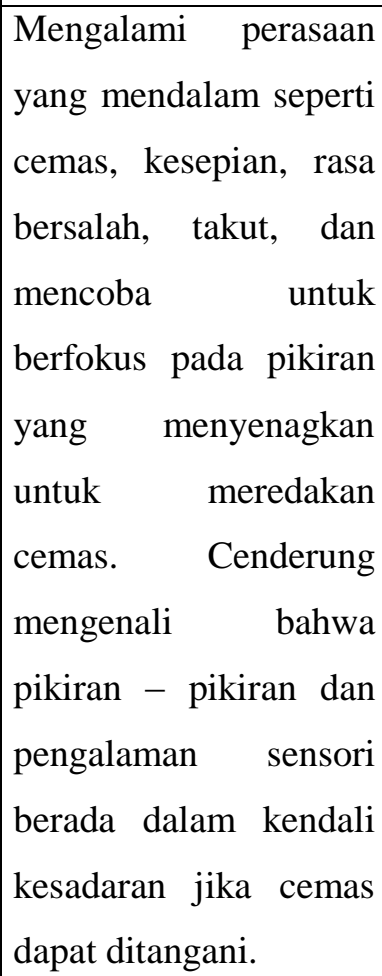 & $\begin{array}{l}\text { Terkadang tersenyum, } \\
\text { tertawa sendiri, } \\
\text { menggerakkan bibir } \\
\text { tanpa suara, pergerakan } \\
\text { mata yag cepat, respon } \\
\text { verbal yang lambat, } \\
\text { diam dan } \\
\text { berkonsentrasi. }\end{array}$ \\
\hline
\end{tabular}




\begin{tabular}{|c|c|c|}
\hline $\begin{array}{l}\text { Condeming : pada } \\
\text { tahapan ini halusinasi } \\
\text { menjadi } \\
\text { menakutkan(cemas } \\
\text { berat) }\end{array}$ & 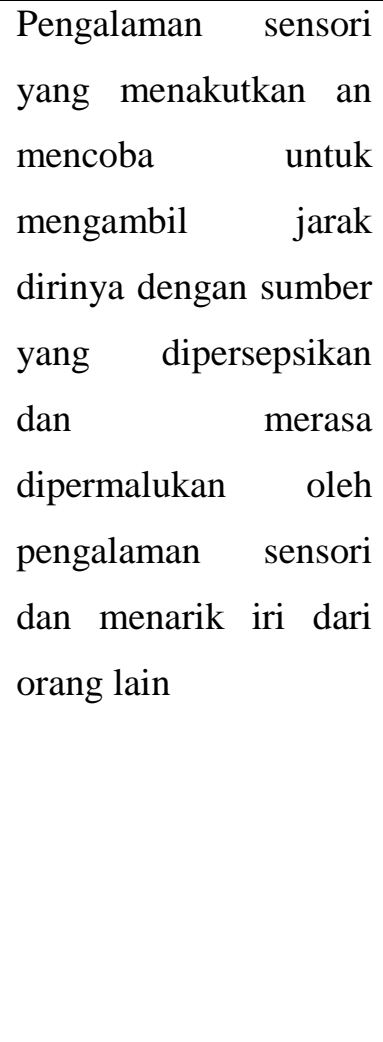 & $\begin{array}{l}\text { Ditandai dengan } \\
\text { meningkatnya tanda }- \\
\text { tanda sistem syaraf } \\
\text { otonom akibat anisieta } \\
\text { otonom seperti } \\
\text { peningkatan denyut } \\
\text { jantung, pernapasan, } \\
\text { dan tekanan darah. } \\
\text { Rentang perhatian } \\
\text { dengan lingkungan } \\
\text { berkurang dan } \\
\text { terkadang asyik dengan } \\
\text { pengalaman sensori dan } \\
\text { kehilangan kemampuan } \\
\text { membedakan halusinasi } \\
\text { dan realita. }\end{array}$ \\
\hline $\begin{array}{l}\text { Controling : pada } \\
\text { tahapan ini halusinai } \\
\text { yang berkuasa } \\
\text { (cemas berat) }\end{array}$ & \begin{tabular}{lr}
\multicolumn{2}{l}{ Menghentikan } \\
perlawanan & terhadap \\
halusinasi & dan \\
menyerah & pada \\
halusinasi & tersebut. Isi \\
halusinasi & menjadi \\
menarik. & Penderita \\
akan & mengalami \\
kesepian jika & sensori \\
halusinasi berhenti.
\end{tabular} & $\begin{array}{l}\text { Penderita taat pada } \\
\text { perintah halusinasi, } \\
\text { sulit berhubungan } \\
\text { dengan orang lain, } \\
\text { respon perhatian } \\
\text { terhadap lingkungan } \\
\text { berkurang dan bila } \\
\text { berhungungan dengan } \\
\text { orang lain hanya } \\
\text { beberapa detik saja, } \\
\text { ketidakmampuan } \\
\text { mengikuti perintah dari } \\
\text { orang lain, tremor dan } \\
\text { berkeringat. }\end{array}$ \\
\hline $\begin{array}{l}\text { Conquering : tahap } \\
\text { halusinasi panik }\end{array}$ & 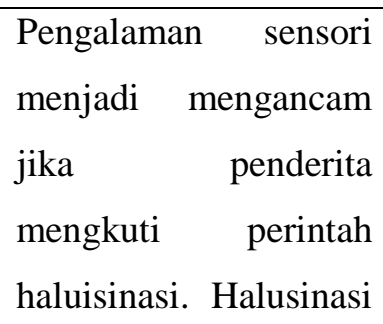 & $\begin{array}{lr}\text { Perilaku panik, resiko } \\
\text { tinggi } \\
\text { bunuh diri } & \text { atau } \\
\text { membunuh. } & \text { Tindak } \\
\text { kekerasan } & \text { agitasi, }\end{array}$ \\
\hline
\end{tabular}




\begin{tabular}{|l|l|lr|}
\hline & $\begin{array}{l}\text { berakhir dari beberapa } \\
\text { jam atau hari jika }\end{array}$ & ketidakmampuan \\
taidak ada intervensi & berrespon pada \\
teraputik. & lingkungan. \\
\hline
\end{tabular}

\subsubsection{Mekanisme Koping}

Mekanisme koping dapat dipengaruhi oleh faktor lingkungan, konsep diri, rasa aman nyaman, pengalaman masa lalu dan tingkat pengetahuan seseorang. Mekanisme koping didefinisikan sebagai strategi untuk memanajemen tingkah laku kepada pemecahan masalah yang paling sederhana dan realistis, berfungsi untuk membebaskan diri dari masalah yang nyata maupun tidak nyata, dan koping merupakan semua usaha secara kognitif dan perilaku untuk mengatasi, mengurangi, dan tahan terhadap tuntutan-tuntutan (Muhith, 2015).

\subsubsection{Penatalaksanaan}

Pengobatan harus secepat mungkin diberikan, disini peran keluarga sangat penting karena setelah mendapat perawatan di rumah sakit pasien dinyatakan boleh pulang sehingga keluarga mempunyai peranan yang sangat penting didalam hal merawat pasien, menciptakan lingkungan keluarga yang kondusif dan sebagai pengawas minum obat (Rossyda, 2019) :

a. Farmakoterapi

Neuroleptika dengan dosis efektif bermanfaat pada penderita skizoprenia yang menahun, hasilnya lebih banyak jika mulai diberi dalam dua tahun penyakit. Neuroleptika dengan dosis efektif tinggi bermanfaat pada penderita dengan psikomotorik yang meningkat.

1. Haloperidol (HLD)

Obat yang dianggap sangat efektif dalam pengelolaan hiperaktivitas, gelisah, agresif, waham, dan halusinasi.

2. Chlorpromazine (CPZ) 
Obat yang digunakan untuk gangguan psikosis yang terkait skizofrenia dan gangguan perilaku yang tidak terkontrol.

3. Trihexilpenidyl (THP)

4. Obat yang digunakan untuk mengobati semua jenis parkinson dan pengendalian gejala ekstrapiramidal akibat terapi obat.

1. Dosis

a) Haloperidol $3 \times 5 \mathrm{mg}$ (tiap 8 jam) intra muscular.

b) Clorpromazin $25-50 \mathrm{mg}$ diberikan intra muscular setiap 6-8 jam sampai keadaan akut teratasi.

2. Dalam keadaan agitasi dan hiperaktif diberikan tablet:

a) Haloperidol 2x1,5 - 2,5 mg per hari.

b) Klorpromazin 2x100 mg per hari c) Triheksifenidil 2x2 mg per hari

3. Dalam keadaan fase kronis diberikan tablet:
a) Haloperidol $2 \times 0,5-1 \mathrm{mg}$ perhari
b) Klorpromazin $1 \times 50 \mathrm{mg}$ sehari (malam)
c) Triheksifenidil 1-2x2 mg sehari
d) Psikosomatik

b. Terapi kejang listrik (Electro Compulsive Therapy)

Terapi kejang listrik adalah pengobatan untuk menimbulkan kejang grandmal secara artifisial dengan melewatkan aliran listrik melalui elektrode yang dipasang pada satu atau dua temples, terapi kejang listrik dapat diberikan pada skizoprenia yang tidak mempan dengan terapi neuroleptika oral atau injeksi, dosis terapi kejang listrik 4-5 jole/detik.

c. Psikoterapi dan rehabilitasi

Psikoterapi suportif individual atau kelompok sangat membantu karena berhubungan dengan praktis dengan maksud mempersiapkan pasien kembali ke masyarakat, selain itu terapi kerja sangat baik untuk mendorong pasien bergaul dengan orang lain, pasien lain, perawat dan dokter. Maksudnya supaya pasien tidak mengasingkan diri karena dapat membentuk kebiasaan yang 
kurang baik, dianjurkan untuk mengadakan permainan atau latihan bersama, seperti terapi modalitas yang terdiri dari :

1. Terapi aktivitas

a. Terapi musik

Fokus : mendengar, memainkan alat musik, bernyanyi.

Yaitu menikmati dengan relaksasi musik yang disukai pasien.

b. Terapi seni

Fokus : untuk mengekspresikan perasaan melalui berbagai pekerjaan seni.

c. Terapi menari

Fokus : ekspresi perasaan melalui gerakan tubuh.

d. Terapi relaksasi

Belajar dan praktek relaksasi dalam kelompok. Rasional : untuk koping/perilaku maladaptif/deskriptif, meningkatkan partisipasi dan kesenangan pasien dalam kehidupan.

2. Terapi sosial

Pasien belajar bersosialisasi dengan pasien lain.

3. Terapi kelompok;

(a) Terapi aktivitas kelompok (adjunctive group activity therapy)

(b) TAK stimulus persepsi : halusinasi

Sesi 1 : mengenal halusinasi.

Sesi 2 : mengontrol halusinasi.

Sesi 3 : Mengontrol halusinasi dengan melakukan kegiatan

Sesi 4 : mencegah halusinasi dengan bercakap-cakap.

Sesi 5 : mengontrol halusinasi dengan patuh minum obat.

4. Terapi lingkungan

Suasana di rumah sakit dibuat seperti suasana di dalam keluarga (home like atmosphere) 


\subsection{Konsep Asuhan Keperawatan}

\subsubsection{Pengkajian Keperawatan}

Pengkajian merupakan pengumpulan data subjektif dan objektif secara, sistematis dengan tujuan membuat penentuan tindakan keperawatan bagi individu, kekuarga dan komunitas. Pengelompokan data pada pengkajian kesehatan dan keperawatan jiwa berupa faktor presipitasi, penilaian stressor, sumber kopping yang dimiliki klien, isi pengkajian meliputi (Waode, 2018) :

a. Identitas klien

Meliputi nama klien, umur, jenis kelamin, status perkawinan, Agama, tanggal MRS, informan, tanggal pengkajian, nomor rumah klien, dan alamat klien.

b. Keluhan utama

Biasanya berupa bicara sendiri, tertawa sendiri, senyum sendiri, menggerakkan bibir tanpa suara, menarik diri dari orang lain, tidak dapat membedakan yang nyata dan tidak nyata, ekspresi muka tegang mudah tersinggung, jengkel dan marah ketakutan biasa terdapat disorientasi waktu tempat dan orang, tidak dapat mengurus diri dan tidak melakukan kegiatan sehari-hari.

c. Faktor predisposisi

Faktor predisposisi adalah faktor resiko yang mempengaruhi jenis dan jumlah sumber yang dapat dibangkitkan oleh individu untuk mengatasi stres. Diperoleh baik dari klien maupun keluarganya, mengenai faktor perkembangan sosial kultural, biokimia psikologis dan genetik yaitu faktor resiko yang mempengaruhi jenis dan jumlah sumber yang dapat dibangkitkan oleh individu untuk mengatasi stres (Rossyda, 2019).

1. Faktor perkembangan ; biasanya tugas perkembangan mengalami hambatan dan hubungan interpersonal terganggu maka individu akan mengalami stres dan kecemasan. 
2. Faktor sosiokultural ; berbagai faktor di masyarakat dapat menyebabkan seseorang merasa disingkirkan oleh kesepian terhadap lingkungan tempat klien dibesarkan.

3. Faktor biokimia ; adanya stres yang berlebihan dialami seseorang maka di dalam tubuh akan dihasilkan suatu zat yang dapat bersifat halusinogenik neuro kimia.

4. Faktor psikologis; hubungan interpersonal yang tidak harmonis, adanya peran ganda yang bertentangan dan tidak diterima oleh anak akan mengakibatkan stres dan kecemasan yang tinggi dan berakhir dengan gangguan orientasi realitas seperti halusinasi.

5. Faktor genetik; Apa yang berpengaruh dalam skizoprenia. Belum diketahui, tetapi Hasil studi menunjukkan bahwa faktor keluarga menunjukkan hubungan yang sangat berpengaruh pada penyakit ini.

d. Faktor presipitasi

Adanya rangsangan lingkungan yang sering yaitu seperti partisipasi klien dalam kelompok, terlalu lama Diajak komunikasi objek yang ada di lingkungan juga suasana sepi / isolasi adalah sering sebagai pencetus terjadinya halusinasi karena hal tersebut dapat meningkatkan stres dan kecemasan yang merangsang tubuh mengeluarkan zat halusinogenik.

e. Aspek fisik Hasil pengukuran tanda vital (TD, nadi, suhu, pernapasan, TB, BB) dan keluhan fisik yang dialami oleh klien. Terjadi peningkatan denyut jantung pernapasan dan tekanan darah.

f. Aspek psikososial Genogram yang menggambarkan tiga generasi.

g. Konsep diri

Konsep diri (self concept) adalah cara pandang dan sikap seseorang terhadap diri sendiri. Konsep diri merupaka inti dari kepribadian seseorang dan sangat berperan dalam menentukan 
dan mengarahkan perkembangan kepribadian serta perilaku seseorang di dalam lingkungannya (Ramdani, 2016).

1. Citra tubuh

Menolak melihat dan menyentuh bagian tubuh yang berubah/ tidak menerima perubahan tubuh yang terjadi / yang akan terjadi. Menolak penjelasan perubahan tubuh, persepsi negatif tentang tubuh. Preokupasi dengan bagian tubuh yang hilang, mengungkapkan keputusasaan, mengungkapkan ketakutan.

2. Identitas diri

Ketidakpastian memandang diri, sukar menetapkan keinginan dan tidak mampu mengambil keputusan.

3. Peran

Berubah / berhenti fungsi peran yang disebabkan penyakit, proses menua putus sekolah dan PHK.

4. Identitas diri

Mengungkapkan keputusasaan karena penyakitnya dan mengungkapkan keinginan yang terlalu tinggi

5. Harga diri

Perasaan malu terhadap diri sendiri, rasa bersalah terhadap diri sendiri, gangguan hubungan sosial, merendahkan martabat, mencederai diri dan kurang percaya diri.

h. Status mental

Pada pengkajian status mental pasien halusinasi ditemukan data berupa bicara sendiri, senyum sendiri, tertawa sendiri, menggerakkan bibir tanpa suara, pergerakan mata yang cepat, respon verbal yang lambat, menarik diri dari orang lain berusaha untuk menghindari orang lain, tidak dapat membedakan yang nyata dan tidak nyata, terjadi peningkatan denyut jantung pernapasan dan tekanan darah, perhatian dengan lingkungan yang kurang/hanya beberapa detik com berkonsentrasi dengan pengalaman sensori, sulit berhubungan 
dengan orang lain, ekspresi muka tegang, mudah tersinggung, jengkel dan marah tidak mampu mengikuti perintah dari perawat, tampak tremor dan berkeringat, perilaku panik, agitasi dan kataton curiga dan bermusuhan, bertindak merusak diri orang lain dan lingkungan, ketakutan, tidak dapat mengurus diri, biasa terdapat disorientasi waktu tempat dan orang (Setiawan, 2017).

i. Mekanisme koping

Apabila mendapat masalah, pasien takut / tidak mau menceritakan kepada orang lain (koping menarik diri). Mekanisme koping yang digunakan pasien sebagai usaha mengatasi kecemasan yang merupakan suatu kesepian nyata yang mengancam dirinya. Mekanisme koping yang sering digunakan pada halusinasi adalah (Caturini, 2014) :

1. Regresi : menjadi malas beraktivitas sehari-hari.

2. Proyeksi : menjelaskan perubahan suatu persepsi dengan berusaha untuk mengalihkan tanggung jawab kepada orang lain.

3. Menarik diri : sulit mempercayai orang lain dan asyik dengan stimulus internal.

j. Aspek medik

Terapi yang diterima klien bisa berupa terapi farmakologi psikomotor terapi okupasional, TAK dan rehabilitas.

\subsubsection{Diagnosa Keperawatan}

Diagnosis keperawatan adalah penilaian klinis tentang respon aktual atau potensial dari individu, keluarga, atau masyarakat terhadap masalah kesehatan/proses kehidupan. Rumusan diagnosis yaitu Permasalahan (P) berhubungan dengan Etiologi (E) dan keduanya ada hubungan sebab akibat secara ilmiah. Rumusan diagnosis keperawatan jiwa mengacu pada pohon masalah yang 
sudah dibuat Diagnosa keperawatan klien dengan halusinasi pendengaran adalah sebagai berikut (Setyani, 2019) :

1. Gangguan persepsi sensori : Halusinasi pendengaran

2. Isolasi sosial

3. Resiko perilaku kekerasan

\subsubsection{Intervensi Keperawatan}

Rencana tindakan pada keluarga (Husein \& Arifin, 2011 dalam Mislika, 2021) adalah :

1. Diskusikan masalah yang dihadap keluarga dalam merawat pasien

2. Berikan penjelasan meliputi : pengertian halusinasi, proses terjadinya halusinasi, jenis halusinasi yang dialami, tanda dan gejala halusinasi, proses terjadinya halusinasi.

3. Jelaskan dan latih cara merawat anggota keluarga yang mengalami halusinasi : menghardik, minum obat, bercakapcakap, melakukan aktivitas.

4. Diskusikan cara menciptakan lingkungan yang dapat mencegah terjadinya halusinasi.

5. Diskusikan tanda dan gejala kekambuhan

6. Diskusikan pemanfaatan fasilitas pelayanan kesehatan terdekat untuk follow upanggota keluarga dengan halusinasi.

Rencana tindakan keperawatan pada klien dengan diagnosa gangguan persepsi sensori halusinasi meliputi pemberian tindakan keperawatan berupa terapi (Mislika, 2021) yaitu :

1. Bantu klien mengenal halusinasinya meliputi isi, waktu terjadi halusinasi, isi, frekuensi, perasaan saat terjadi halusinasi respon klien terhadap halusinasi mengontrol halusinasi dengan cara menghardik.

2. Meminum obat secara teratur.

3. Melatih bercakap-cakap dengan orang lain.

4. Menyusun kegiatan terjadwal dan dengan aktifitas 


\subsubsection{Implementasi Keperawatan}

Perencanaan yaitu tahapan dari proses keperawatan atau tahap penentuan apa yang akan dilakukan untuk membantu klien. Implementasi disesuaikan dengan rencana tindakan keperawatan. Pada situasi nyata sering pelaksanaan jauh berbeda dengan rencana, hal ini terjadi karena perawat belum terbiasa menggunakan rencana tertulis dalam melaksanakan tindakan keperawatan. Sebelum melaksanakan tindakan keperawatan yang sudah direncanakan, perawat perlu memvalidasi dengan singkat apakah rencana tindakan masih sesuai dan dibutuhkan klien sesuai dengan kondisinya (here and now). Perawat juga menilai diri sendiri, apakah kemampuan interpersonal, intelektual, tekhnikal sesuai dengan tindakan yang akan dilaksanakan, dinilai kembali apakah aman bagi klien. Setelah semuanya tidak ada hambatan maka tindakan keperawatan boleh dilaksanakan. Adapun pelaksanaan tindakan keperawatan jiwa dilakukan berdasarkan Strategi Pelaksanaan (SP) yang sesuai dengan masing-masing masalah utama. Pada masalah gangguan sensori persepsi: halusinasi pendengaran, terdapat 2 jenis SP, yaitu SP Klien dan SP Keluarga (Gaol, 2021).

SP klien terbagi menjadi SP 1 (membina hubungan saling percaya, mengidentifikasi halusinasi "jenis, isi, waktu, frekuensi, situasi, perasaan dan respon halusinasi”, mengajarkan cara menghardik, memasukan cara menghardik ke dalam jadwal; SP 2 (mengevaluasi SP 1, mengajarkan cara minum obat secara teratur, memasukan ke dalam jadwal); SP 3 (mengevaluasi SP 1 dan SP 2, menganjurkan klien untuk mencari teman bicara); SP 4 (mengevaluasi SP 1, SP 2, dan SP 3, melakukan kegiatan terjadwal). SP keluarga terbagi menjadi SP 1 (membina hubungan saling percaya, mendiskusikan masalah yang dihadapi keluarga dalam merawat pasien, menjelaskan pengertian, tanda dan gejala helusinasi, jenis 
halusinasi yang dialami klien beserta proses terjadinya, menjelaskan cara merawat pasien halusinasi); SP 2 (melatih keluarga mempraktekan cara merawat pasien dengan halusinasi, melatih keluarga melakukan cara merawat langsung kepada pasien halusinasi); SP 3 (membantu keluarga membuat jadwal aktivitas di rumah termasuk minum obat (discharge planing), menjelaskan follow up pasien setelah pulang). Pada saat akan dilaksanakan tindakan keperawatan maka kontrak dengan klien dilaksanakan dengan menjelaskan apa yang akan dikerjakan dan peran serta klien yang diharapkan, dokumentasikan semua tindakan yang telah dilaksanakan serta respon klien (Gaol, 2021).

\subsubsection{Evaluasi}

Evaluasi adalah proses berkelanjutan untuk menilai efek dari tindakan keperawatan pada klien. Evaluasi dilakukan dengan tindakan keperawatan yang telah dilaksanakan. Evaluasi dapat dibagi dua yaitu evaluasi proses dan evaluasi formatif, dilakukan setiap selesai melaksanakan tindakan evaluasi hasil atau sumatif dilakukan dengan membandingkan respon klien pada tujuan yang telah ditentukan (Puspita, 2020). 


\section{BAB III \\ TINJAUAN KASUS}

\subsection{Identitas Klien}

$\begin{array}{ll}\text { Inisial } & \text { : Ny. P } \\ \text { Jenis Kelamin } & \text { : Perempuan } \\ \text { Umur } & : \text { 70 Tahun } \\ \text { Agama } & : \text { Budha } \\ \text { Tanggal Pengkajian } & : \text { 04 Maret 2021 } \\ \text { Informan } & : \text { Klien }\end{array}$

\subsection{Alasan Masuk}

Alasan klien masuk yayasan pemenangan jiwa adalah klien mengatakan klien sering berbicara sendiri, suka menyendiri, melamun, dan mendengar suara-suara tanpa wujud. Saudara klien semuanya sudah menikah, dan tidak mampu mengurus klien sehingga klien diantar ke yayasan pemenang jiwa.

\subsection{Faktor Predisposisi}

Klien sebelumnya pernah mengalami gangguan jiwa \pm 10 Tahun yang lalu tepatnya pada tahun 2010. Klien, suka menyendiri, melamun, sering bicara sendiri, mondar mandir, mendengar suara-suara tanpa wujud, tertawa sendiri akhirnya keluarga membawa klien ke RSJ. Keluarga klien tidak ada yang pernah mengalami gangguan jiwa. Hal ini dialami karena klien diselingkuhi oleh suaminya, sehingga klien menjadi depresi dan tidak dapat menerima kenyataan.

Masalah Keperawatan : Halusinasi

\subsection{Fisik}

Klien tidak memiliki keluhan fisik, saat dilakukan pemeriksaan tanda tanda vital, didapatkan hasil TD : 120/80 mmHg ; $\mathrm{N}: 82 \mathrm{x} / \mathrm{i} ; \mathrm{S}: 36,5^{\circ} \mathrm{C} ; \mathrm{P}$ : 20x/i. Klien memiliki tinggi badan $159 \mathrm{~cm}$ dan berat badan $58 \mathrm{Kg}$. 


\subsection{Psikososial}

\subsubsection{Genogram}

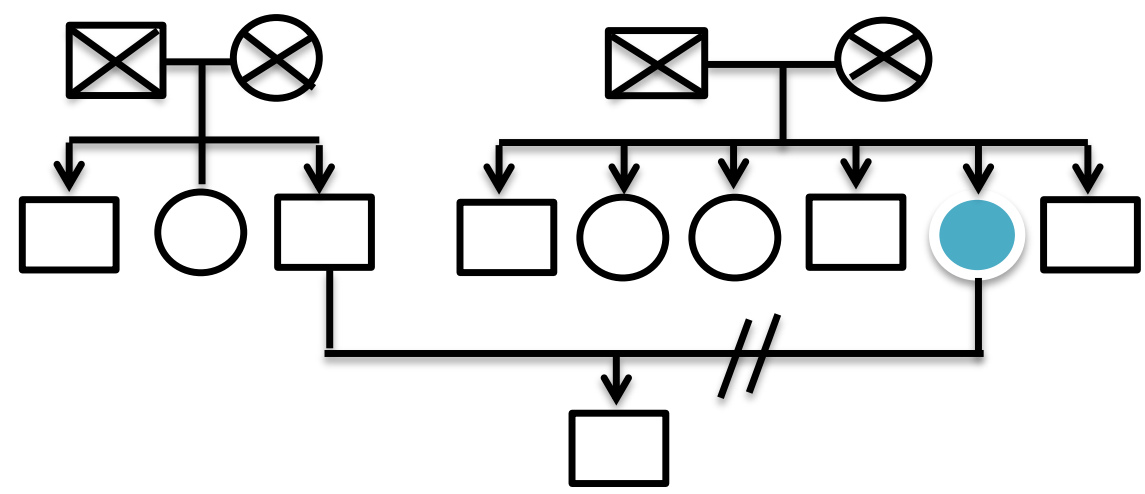

Penjelasan :

Klien merupakan anak kelima dari enam bersaudara, klien berinisial Ny. P. Kedua orang tua klien sudah meninggal saat usia klien 52 tahun, klien memiliki 3 saudara laki-laki, dan 2 saudara perempuan. Ny. P sudah menikah, namun sudah bercerai dengan suaminya, mereka sudah memiliki 1 anak.

Keterangan :

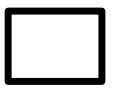

: Laki-laki

Klien

: Perempuan

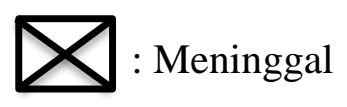

// : Bercerai

8 : Meninggal

1 : Garis Keturunan 


\subsubsection{Konsep diri}

a. Gambaran diri :

Klien menyukai seluruh tubuhnya dan tidak ada yang cacat.

b. Identitas diri :

Klien memiliki latar belakang pendidikan terakhir SD, sebelum dirawat di RSJ klien pernah bekerja sebagai tukang jahit dan klien merasa senang dengan pekerjaannya.

c. Peran diri

Sebelum sakit, pasien mempuyai tanggung jawab sebagai tulang punggung keluarga karena suami pengangguran dan ada anak yang mesti disekolahkan. Pasien menutup usaha nya karena merasa sangat kecewa dan sia-sia. Klien meninggalkan anaknya kepada suaminya.

d. Ideal diri :

Klien merasa malu karena klien gagal dalam membina rumah tangganya.

e. Harga diri :

Klien mengatakan bahwa dirinya merasa sangat malu dengan lingkunganya. Klien merasa dirinya tidak dihargai sejak dirinya ditinggal suaminya.

Masalah keperawatan : Harga Diri Rendah

\subsubsection{Hubungan sosial}

a. Orang yang berarti

Klien mengganggap bahwa keluarganya adalah orang yang sangat berarti dalam hidupnya, terutama orangtuanya.

b. Peran serta dalam kegiatan kelompok/masyarakat

Sebelum sakit klien adalah orang yang sangat giat bekerja, beberapa kali ikut acara keagamaan dan klien adalah orang yang ramahdengan tetangga. Setelah suami selingkuh dan menikah lagi klien menjadi orang yang sangat tertutup dan tidak berkomunikasi lagi dengan orang di lingkunganya. 
Setelah masuk RSJ klien beberapa kali mengikuti kegiata TAK agar dirinya merasa lebih senang.

c. Hambatan Berhubungan dengan orang lain :

Klien mengatakan mempunyai hambatan dalam berhubungan dengan orang lain karena klien sulit bergaul dan selalu ingin menyendiri.

Masalah keperawatan : Isolasi Sosial : Menarik diri

\subsubsection{Spiritual}

a. Nilai dan Keyakinan :

Klien beragama Budha dan yakin dengan agamanya. Klien juga mengatak setiap pagi selalu melakukan sembahyang.

b. Kegiatan Ibadah :

c. Klien ikut melakukan ibadah selama dirawat.

\subsubsection{Status Mental}

1. Penampilan

Klien tampak rapi dalam berpakaian

2. Pembicaraan

Klien masih mampu menjawab pertanyaan perawat dengan lambat namun dapat dipahami

3. Aktivitas Motorik

Klien mengatakan bisa melakukan aktivitas sehari - hari.

4. Suasana perasaan

Klien sedih karena tinggal di yayasan,

Masalah keperawatan : Harga Diri Rendah

5. Afek

Afek wajah sesuai dengan topic pembicaraan

6. Interaksi selama wawancara

Klien kooperatif saat wawancara 


\section{Persepsi}

Klien mengatakan bahwa ia mendengar ada suara-suara Masalah keperawatan : Gangguan persepsi sensori : halusinasi

8. Proses Pikir

Klien mampu menjawab apa yang ditanya dengan baik.

9. Isi pikir

Klien dapat mengontrol isi pikirnya,klien tidak mengalami gangguan isi pikir dan tidak ada waham. Klien tidak mengalami fobia, obsesi ataupun depersonalisasi.

10. Tingkat kesadaran

Klien tidak mengalami gangguan orientasi, klien mengenali waktu, orang dan tempat.

11. Memori

Klien mampu menceritakan kejadian di masa lalu dan yang baru terjadi.

12. Tingkat konsentrasi berhitung

Klien mampu berkonsentrasi dalam perhitungan sederhana tanpa bantuan orang lain.

13. Kemampuan penilaian

Klien dapat membedakan hal yang baik dan yang buruk (mampu melakukan penilaian).

14. Daya tilik diri

Klien tidak mengingkari penyakit yang diderita, klien mengetahui bahwa dia sedang sakit dan dirawat di rumah sakit jiwa.

\subsection{Mekanisme Koping}

Klien mengalami mekanisme koping adaptif yaitu klien dapat berbicara baik dengan orang lain. 


\subsection{Masalah Psikososial dan Lingkungan}

Klien mengatakan sulit berteman dengan orang lain karena klien selalu ingin menyendiri.

\subsection{Pengetahuan Kurang Tentang Gangguan Jiwa}

Klien mengetahui tentang gangguan jiwa dan klien paham tentang penyakitnya dan apa saja obat yang harus diminum dan kapan saja.

\subsection{Aspek Medik}

Diagnosa medis : Skizofrenia Paranoid

Terapi medis yang diberikan :

Resperidon tablet $2 \mathrm{mg} 2 \mathrm{x} 1$

\subsection{Analisa Data}

\begin{tabular}{|c|c|c|}
\hline No & Data & Masalah Keperawatan \\
\hline 1. & $\begin{array}{l}\text { DS : } \\
\text { - } \quad \text { Klien merasa tidak berguna } \\
\text { karena tidak dapat membantu } \\
\text { keluarga. } \\
\text { - } \quad \text { Klien sedih berada di Yayasan } \\
\quad \text { Pemenang Jiwa } \\
\text { - } \quad \text { Klien merasa malu karena gagal } \\
\quad \text { dalam pernikahannya. } \\
\text { DO : } \\
\text { - Klien tampak murung } \\
\text { - Lebih banyak diam } \\
\text { - Nada bicara pelan }\end{array}$ & $\begin{array}{l}\text { Gangguan konsep diri : } \\
\text { Harga diri rendah }\end{array}$ \\
\hline 2. & $\begin{array}{l}\text { DS : } \\
\begin{array}{l}\text { - Klien mengatakan bahwa klien } \\
\text { sering berteriak - teriak di } \\
\text { rumah } \\
\text { - Klien sering mendengarkan }\end{array}\end{array}$ & $\begin{array}{ll}\text { Gangguan } & \text { Persepsi } \\
\text { Sensori : } & \text { Halusinasi } \\
\text { Pendengaran } & \end{array}$ \\
\hline
\end{tabular}




\begin{tabular}{|c|c|c|}
\hline & $\begin{array}{l}\text { suara } \\
\text { - Suara tanpa wajah yang } \\
\text { menyuruhnya untuk melukai } \\
\text { dirinya } \\
\text { - } \text { Klien mengatakan suara -suara } \\
\text { tersebut muncul 1 kali dalam } \\
\text { sehari, muncul pada saat klien } \\
\text { sedang menyendiri di pagi hari } \\
\text { - Klien merasa gelisah dan takut } \\
\text { jika mendengar suara tersebut. } \\
\text { DO : } \\
\text { Klien sering marah-marah, } \\
\text { mondar-mandir, berbicara } \\
\text { sendiri, berbicara ngawur, } \\
\text { sering senyum-senyum sendiri. }\end{array}$ & \\
\hline 3. & $\begin{array}{l}\text { DS : } \\
\text { - } \quad \text { Klien jarang mengikuti kegiatan } \\
\text { di kelompok di masyarakat } \\
\text { - } \quad \text { Kilen mengatakan mempunyai } \\
\text { hambatan dengan orang lain } \\
\text { - } \quad \text { Klien mengatakan lebih suka } \\
\text { menyendiri } \\
\text { DO : } \\
\text { - Klien suka menyendiri } \\
\text { - Klien tidak mau berintraksi } \\
\text { dengan orang lain } \\
\text { - Klien jarang berkumpul dengan } \\
\text { orang lain }\end{array}$ & $\begin{array}{l}\text { Isolasi sosial : Menarik } \\
\text { diri }\end{array}$ \\
\hline
\end{tabular}




\subsection{Masalah Keperawatan}

1. Gangguan Persepsi Sensori : Halusinasi Pendengaran

2. Gangguan Konsep Diri : Harga Diri Rendah

3. Isolasi Sosial : Menarik Diri

\subsection{Pohon Masalah}

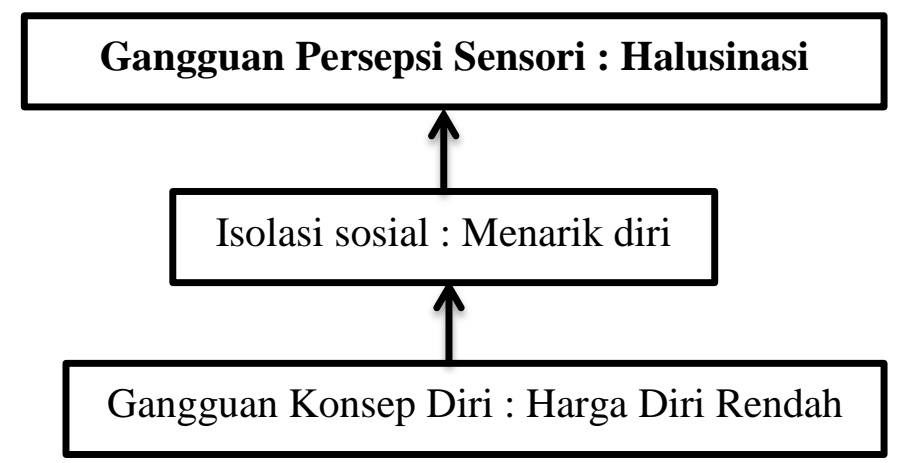

\subsection{Prioritas Diagnosa Keperawatan}

1. Gangguan Persepsi Sensorik : Halusinasi Pendengaran

2. Gangguan Konsep Diri : Harga Diri Rendah

\subsection{Intervensi Keperawatan}

\begin{tabular}{|c|c|c|}
\hline No & Diagnosa Keperawatan & Intervensi \\
\hline 1. & $\begin{array}{l}\text { Gangguan Persepsi Sensori : } \\
\text { Halusinasi Pendengaran } \\
\text { DO: } \\
\text { - } \text { Klien sering, mondar - } \\
\text { mandir, berbicara } \\
\text { sendiri, berbicara } \\
\text { ngawur, sering } \\
\text { senyum-senyum } \\
\text { sendiri. } \\
\text { DS: } \\
\text { Klien mengatakan } \\
\text { bahwa klien sering }\end{array}$ & $\begin{array}{l}\text { SP 1: } \\
\text { 1. Identifikasi isi, waktu terjadi, } \\
\text { situasi pencetus, dan respon } \\
\text { terhadap halusinasi } \\
\text { 2. Jelaskan dan Latih teknik } \\
\quad \text { menghardik } \\
\text { SP } 2 \text { : } \\
\text { Kontrol Halusinasi klien dengan } \\
\text { minum obat secara teratur } \\
\text { SP } 3 \text { : } \\
\text { Ajarkan cara mengontrol } \\
\text { halusinasi dengan bercakap - }\end{array}$ \\
\hline
\end{tabular}




\begin{tabular}{|c|c|c|}
\hline & 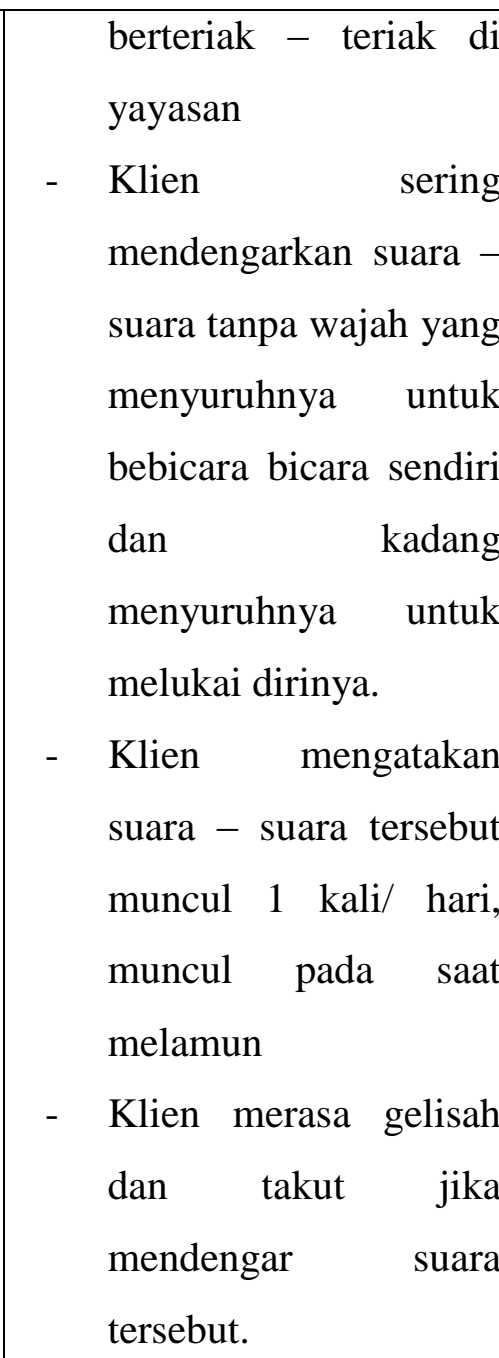 & \begin{tabular}{l}
\multicolumn{3}{l}{ cakap dengan orang lain } \\
SP 4 : \\
Ajarkan cara mengontrol \\
halusinasi dengan melakukan \\
kegiatan terjadwal
\end{tabular} \\
\hline 2. & $\begin{array}{l}\text { Gangguan Konsep Diri : } \\
\text { Harga Diri Rendah } \\
\text { DS: } \\
\text { - Klien merasa tidak } \\
\text { berguna karena tidak } \\
\text { dapat membantu } \\
\text { keluarga. } \\
\text { Klien merasa minder } \\
\text { karena penyakit yang } \\
\text { di alaminya } \\
\text { - Klien sedih berada di } \\
\text { yayasan } \\
\text { Klien merasa malu }\end{array}$ & $\begin{array}{l}\text { SP 1: } \\
\text { Identifikasi Kemampuan dan } \\
\text { aspek positif yang di miliki klien } \\
\text { SP 2: } \\
\text { Latih kegiatan sesuai kemampuan } \\
\text { yang dipilih pertama } \\
\text { SP } 3: \\
\text { Latih kegiatan sesuai kemampuan } \\
\text { yang dipilih kedua } \\
\text { SP } 4 \text { : } \\
\text { Latih kegiatan sesuai kemampuan } \\
\text { yang dipilih ketiga }\end{array}$ \\
\hline
\end{tabular}




\begin{tabular}{|c|c|c|}
\hline & $\begin{array}{l}\text { dalam menajlin asmara } \\
\text { DO: } \\
\text { - } \quad \text { Klien tampak murung } \\
\text { - } \quad \text { Lebih banyak diam }\end{array}$ & \\
\hline 3. & $\begin{array}{l}\text { Isolasi Sosial : Menarik Diri } \\
\text { DS : } \\
\text { - Klien jarang mengikuti } \\
\text { kegiatan di kelompok } \\
\text { di masyarakat. } \\
\text { - Kilen mengatakan } \\
\text { mempunyai hambatan } \\
\text { dengan orang lain. } \\
\text { Klien mengatakan } \\
\text { lebih suka menyendiri } \\
\text { DO : } \\
\text { - Klien menyendiri } \\
\text { - Klien Tidak mau } \\
\text { berintraksi dengan } \\
\text { orang lain jarang } \\
\text { Klien dengan } \\
\text { berkumpul dain } \\
\text { orang lan }\end{array}$ & $\begin{array}{l}\text { SP 1: } \\
\text { Menjelaskan keuntungan dan } \\
\text { kerugian mempunyai teman } \\
\text { SP } 2 \text { : } \\
\text { Melatih klen berkenalam dengan } 2 \\
\text { orang atau lebih } \\
\text { SP } 3 \text { : } \\
\text { Melatih bercakap cakap sembil } \\
\text { melakukan kegiatan harian } \\
\text { SP } 4 \text { : } \\
\text { Melatih berbicara sosial, meminta } \\
\text { sesuatu, berbelanja dan sebagainya }\end{array}$ \\
\hline
\end{tabular}


3.15 IMPLEMENTASI \& EVALUASI

\begin{tabular}{|c|c|c|}
\hline Hari/Tgl & Implementasi & Evaluasi \\
\hline $\begin{array}{l}\text { Jumat, } \\
05 \text { Maret } 2021 \\
10.00 \text { s/d selesai }\end{array}$ & $\begin{array}{l}\text { 1. Data } \\
\text { - Klien sering, mondar - mandir, berbicara sendiri, } \\
\text { berbicara ngawur, sering senyum-senyum sendiri, sering } \\
\text { mengarahkan telinganya ke tempat - tempat tertentu. } \\
\text { - } \quad \text { Klien sering mendengarkan suara - suara tanpa wajah } \\
\text { yang menyuruhnya untuk berbicara bicara sendiri. } \\
\text { - Klien mengatakan suara - suara tersebut muncul } 1 \text { kali/ } \\
\text { hari, muncul pada saat melamun } \\
\text { - Klien merasa gelisah dan takut jika mendengar suara } \\
\text { 2. Diagnosa Keperawatan } \\
\text { Gangguan sensori persepsi : halusinasi pendengaran } \\
\text { 3. Intervensi Keperawatan } \\
\text { SP } 1 \\
\text { a. Identifikasi jenis halusinasi } \\
\text { b. Identifikasi isi halusinasi } \\
\text { c. Identifikasi waktu halusinasi } \\
\text { d. Identifikasi frekuensi halusinasi }\end{array}$ & $\begin{array}{l}\text { S : } \\
\text { Senang } \\
\text { O : } \\
\text { - Klien mampu mengenali halusinasinya } \\
\text { dengan mandiri } \\
\text { - Klien mampu menghardik halusinasinya } \\
\quad \text { dengan motivasi perawat } \\
\text { A : } \\
\text { Halusinasi pendengaran (+) } \\
\text { P : } \\
\text { - Latihan mengidentifikasi halusinasi : isi, } \\
\quad \text { frekuensi, waktu terjadi, situasi pencutus, } \\
\quad \text { perasaan dan respon halusinasi. }\end{array}$ \\
\hline
\end{tabular}




\begin{tabular}{|c|c|c|}
\hline & $\begin{array}{l}\text { e. Identifikasi situasi yang menyebabkan halusinasi } \\
\text { f. Identifikasi respon klien terhadap halusinasi } \\
\text { g. Latih cara mengontrol halusinasi dengan menghardik } \\
\text { 4. Implementasi Keperawatan } \\
\text { a. Mengidentifikasijenis halusinasi } \\
\text { b. Mengidentifikasi isi halusinasi } \\
\text { c. Mengidentifikasi waktu halusinasi } \\
\text { d. Mengidentifikasi frekuensi halusinasi } \\
\text { e. Mengidentifikasi situasi yang menyebabkan halusinasi } \\
\text { f. Mengidentifikasi respon klien terhadap halusinasi } \\
\text { g. Melatih cara mengontrol halusinasi dengan menghardik } \\
\text { Rencana Tindak Lanjut : } \\
\text { SP } 2 \text { (Latih cara minum obat secara teratur) }\end{array}$ & \\
\hline $\begin{array}{l}\text { Sabtu, } \\
6 \text { Maret } 2021 \\
10.00 \text { s/d selesai }\end{array}$ & \begin{tabular}{|l} 
1. Data \\
- $\quad$ Klien mengatakan mendengar suara-suara tersebut namun \\
sudah bisa mengendalikan suara-suara tersebut dengan \\
cara menghardik dan bercakap-cakap dengan orang lain. \\
- $\quad$ Klien juga mau melakukan aktivitas sesuai dengan jadwal \\
$\quad$ yang sudah disusun \\
- \\
Klien masih nampak berbicara sendiri sesekali
\end{tabular} & $\begin{array}{l}\text { S : } \\
\text { Klien senang dan antusias. } \\
\text { O: } \\
\text { Klien mampu mengontrol halusinasi dengan } \\
\text { minum obat } 2 \text { kali dalam sehari. } \\
\text { A : } \\
\text { Halusinasi pendengaran }(+)\end{array}$ \\
\hline
\end{tabular}




\begin{tabular}{|c|c|c|}
\hline & 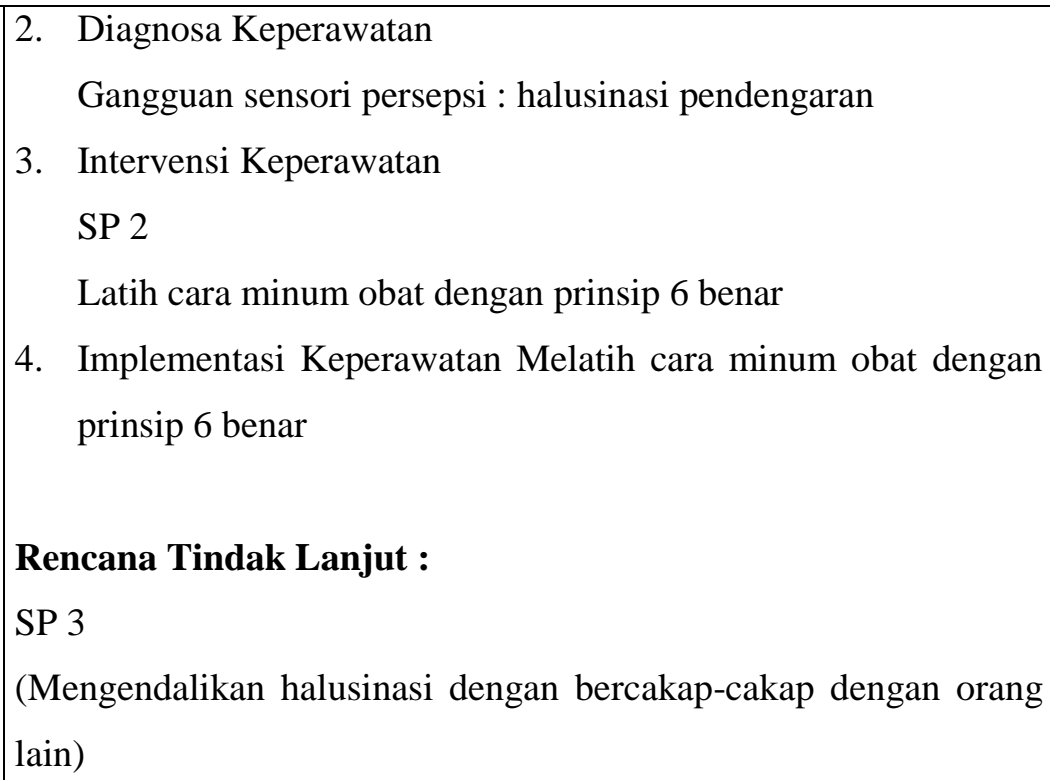 & $\begin{array}{l}\text { P : } \\
\text { - Latihan mengidentifikasi halusinasi : isi, } \\
\text { frekuensi, waktu terjadi, situasi pencetus, } \\
\text { perasaan dan respon halusinasi } \\
\text { - Latihan menghardik halusinasi } 3 \text { kali } \\
\text { sehari } \\
\text { - Latihan minum obat dengan prinsip } 6 \\
\text { benar } 2 \text { kali sehari }\end{array}$ \\
\hline $\begin{array}{l}\text { Senin, } \\
08 \text { Maret } 2021 \\
11.00 \text { s/d selesai }\end{array}$ & $\begin{array}{l}\text { 1. Data } \\
\text { - Klien mengatakan mendengar suara - suara yang isinya “ } \\
\text { Melukai dirinya” } \\
\text { - } \text { Klien mengatakan Suara-suara itu muncul waktu pagi } \\
\quad \text { hari. } \\
\text { - } \\
\quad \text { Klien tampak bicara-bicara sendiri. Mulut klien tampak } \\
\quad \text { komat-kamit. }\end{array}$ & $\begin{array}{l}\text { S: } \\
\text { Klien dia merasa senang bisa bercakapcakap } \\
\text { dengan orang lain } \\
\mathrm{O}: \\
\text { - Klien nampak sesekali berbicara sendiri } \\
\text { dan menutup kupingnya (menghardik } \\
\text { halusinasi) }\end{array}$ \\
\hline
\end{tabular}




\begin{tabular}{|c|c|c|}
\hline & $\begin{array}{l}\text { 2. Diagnosa Keperawatan } \\
\text { Gangguan sensori persepsi : halusinasi pendengaran } \\
\text { 3. Intervensi Keperawatan } \\
\text { SP } 3 \\
\text { Latih mengendalikan halusinasi dengan bercakap -cakap } \\
\text { dengan orang lain } \\
\text { 4. Implementasi Keperawatan } \\
\quad \text { Melatih mengendalikan halusinasi dengan bercakap-cakap } \\
\text { dengan orang lain } \\
\text { Rencana Tindak Lanjut : } \\
\text { SP } 4 \text { (Mengendalikan halusinasi dengan melakukan kegiatan yang } \\
\text { biasa dilakukan di yayasan) }\end{array}$ & $\begin{array}{l}\text { cakap dengan orang lain } \\
\text { A : } \\
\text { Halusinasi pendengaran }(+) \\
\text { P : } \\
\text { - Latihan menghardik halusinasi } 3 \text { kali } \\
\text { sehari } \\
\text { - Latihan minum obat dengan prinsip } 6 \\
\text { benar } 2 \text { kali sehari }\end{array}$ \\
\hline $\begin{array}{l}\text { Kamis, } \\
11 \text { Maret } 2021 \\
10.00 \text { s/d selesai }\end{array}$ & $\begin{array}{l}\text { 1. Data } \\
\text { - Klien mengatakan masih mendengar suara-suara tersebut } \\
\text { namun sudah bisa mengendalikan suara-suara tersebut } \\
\text { dengan cara menghardik dan bercakap-cakap dengan } \\
\text { orang lain. } \\
\text { - Klien mengatakan mau melamun karena tidak ada } \\
\text { kegiatan. }\end{array}$ & $\begin{array}{l}\text { S : Klien mengatakan biasa memetik sayur dan } \\
\text { Menyusun piring. O : - Klien mampu } \\
\text { melakukan kegiatan yang biasa dilakukannya } \\
\text { di Yayasan dan kegiatan tersebut dijadwal A : } \\
\text { Halusinasi pendengaran }(+) \\
\text { P : - Latihan menghardik halusinasi } 3 \text { kali } \\
\text { sehari - Latihan minum obat dengan prinsip } 6\end{array}$ \\
\hline
\end{tabular}




\begin{tabular}{|c|c|c|}
\hline & 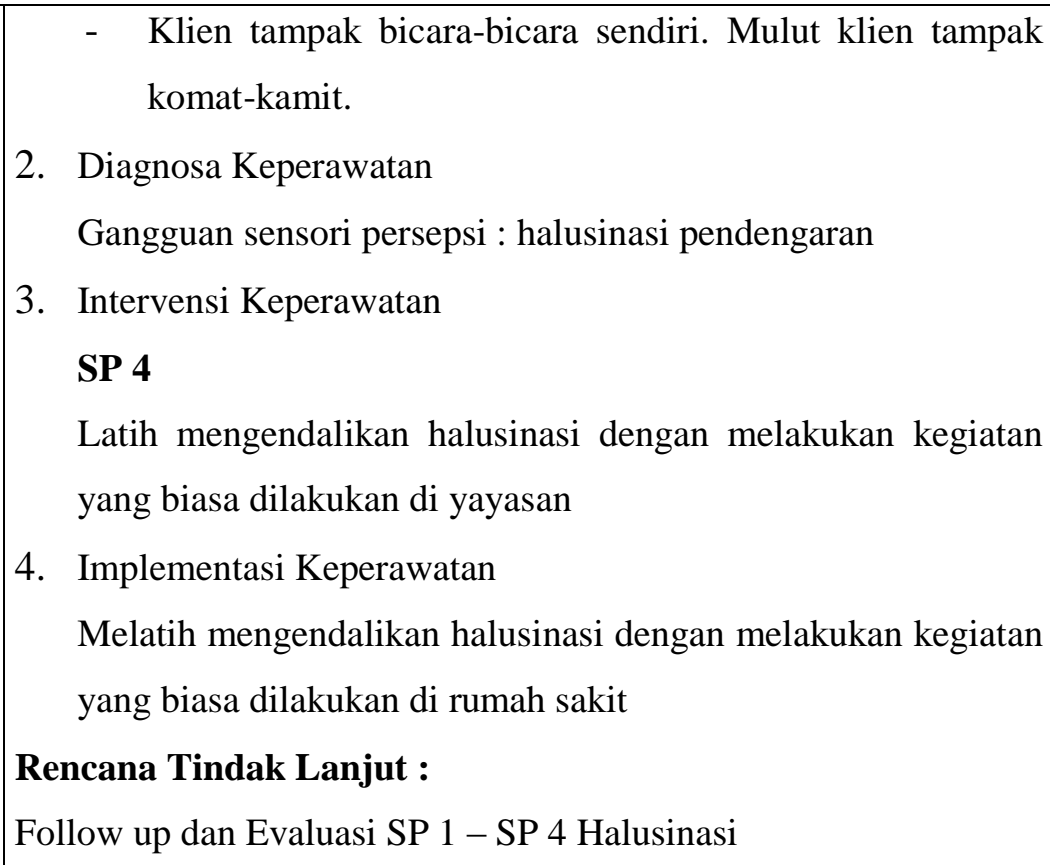 & $\begin{array}{l}\text { benar } 2 \text { kali sehari - Latihan bercakap-cakap } \\
\text { dengan orang lain } 3 \text { kali sehari - Melakukan } \\
\text { aktivitas terjadwal setiap hari }\end{array}$ \\
\hline $\begin{array}{l}\text { Rabu, } \\
17 \text { Maret } 2021 \\
10.00 \text { s/d selesai }\end{array}$ & $\begin{array}{l}\text { 1. Data : } \\
\text { - Klien merasa tidak berguna karena tidak dapat } \\
\text { membantu keluarga. } \\
\text { - Klien merasa minder karena penyakit yang di } \\
\text { alaminya } \\
\text { - Klien sedih berada di yayasan } \\
\text { - Klien merasa malu dalam menajlin asmara }\end{array}$ & $\begin{array}{l}\text { S : } \\
\text { Antusias dan bersemangat } \\
\text { O : } \\
\text { Klien mampu Mengidentifikasi aspek } \\
\text { positif yang dimiliki pasien yaitu berdoa } \\
\text { dan bersyukur. } \\
\text { A : }\end{array}$ \\
\hline
\end{tabular}




\begin{tabular}{|c|c|c|}
\hline & $\begin{array}{l}\text { - Klien tampak murung } \\
\text { - } \text { Lebih banyak diam } \\
\text { 2. Diagnosa Keperawatan } \\
\text { Gangguan Konsep Diri : Harga Diri Rendah } \\
\text { 3. Tindakan Keperawatan } \\
\text { Sp } 1 \text { : } \\
\text { Mengidentifikasi kemampuan dan aspek positif yang } \\
\text { dimiliki pasien } \\
\text { RTL : } \\
\text { SP } 2 \\
\text { a. Menilai kemampuan yang dapat digunakan } \\
\text { b. Menetapkan atau memilih kegiatan sesuai kemampuan } \\
\text { c. Melatih kegiatan sesuai kemampuan yang dipilih } 1\end{array}$ & $\begin{array}{l}\text { Harga Diri Rendah }(+) \\
\text { P : } \\
\text { Klien selalu memulai segala aktivitas nya } \\
\text { dengan bersyukur dan Doa. }\end{array}$ \\
\hline $\begin{array}{l}\text { Jumat, } \\
19 \text { Maret } 2021 \\
11.00 \text { s/d selesai }\end{array}$ & $\begin{array}{l}\text { 1. Data : } \\
\text { - Klien merasa tidak berguna karena tidak dapat } \\
\text { membantu keluarga. } \\
\text { - Klien merasa minder karena penyakit yang di } \\
\quad \text { alaminya }\end{array}$ & $\begin{array}{l}\text { S : } \\
\text { Senang dan antusias } \\
\text { O : } \\
\text { Klien mampu memilih dan melatih } \\
\text { kegiatan sesuai kemampuan yaitu masak. }\end{array}$ \\
\hline
\end{tabular}




\begin{tabular}{|c|c|c|}
\hline & $\begin{array}{l}\text { - Klien sedih berada di yayasan } \\
\text { - } \text { Klien merasa malu dalam menajlin asmara } \\
\text { - } \text { Klien tampak murung } \\
\text { - } \text { Lebih banyak diam } \\
\text { 2. Diagnosa Keperawatan } \\
\text { Gangguan Konsep Diri : Harga Diri Rendah } \\
\text { 3. Tindakan Keperawatan } \\
\text { Sp } 2 \text { Harga Diri Rendah : } \\
\text { a. Menilai kemampuan yang dapat digunakan } \\
\text { b. Menetapkan atau memilih kegiatan sesuai } \\
\text { c. Memampuan } \\
\text { RTL : } \\
\text { Sp } 3 \text { : Melatih kegiatan sesuai kemampuan yang dipilih } 2\end{array}$ & $\begin{array}{l}\text { A : } \\
\text { Harga Diri Rendah }(+) \\
\text { P : } \\
\text { Klien melatih kemampuan memasak yang } \\
\text { dimiliki nya }\end{array}$ \\
\hline $\begin{array}{l}\text { Senis, } \\
22 \text { Maret } 2021 \\
10.00 \text { s/d selesai }\end{array}$ & 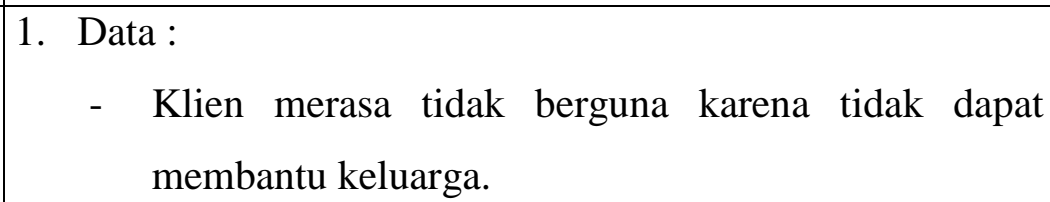 & $\begin{array}{l}\text { S : } \\
\text { Senang dan antusias } \\
\mathrm{O}:\end{array}$ \\
\hline
\end{tabular}




\begin{tabular}{|c|c|c|}
\hline & $\begin{array}{l}\text { - } \text { Klien merasa minder karena penyakit yang di } \\
\quad \text { alaminya } \\
\text { - } \text { Klien sedih berada di yayasan } \\
\text { - Klien merasa malu dalam menajlin asmara } \\
\text { - Klien tampak murung } \\
\text { - Lebih banyak diam } \\
\text { 2. Diagnosa Keperawatan } \\
\text { Gangguan Konsep Diri : Harga Diri Rendah } \\
\text { 3. Tindakan Keperawatan } \\
\text { Sp } 3 \text { : } \\
\text { Melatih kegiatan sesuai kemampuan yang dipilih } 2 \\
\text { RTL : } \\
\text { Sp } 4 \text { : Melatih kegiatan sesuai kemampuan yang dipilih } 3\end{array}$ & $\begin{array}{l}\text { Klien mampu melatih kegiatan sesuai } \\
\text { kemampuan yaitu menyuci piring. } \\
\text { A : } \\
\text { Harga Diri Rendah (+) } \\
\text { P : } \\
\text { - Berdoa, Mengikuti ibadah } \\
\text { - Membantu Masak } \\
\text { - Menyuci piring }\end{array}$ \\
\hline $\begin{array}{l}\text { Kamis, } \\
25 \text { Maret } 2021 \\
10.00 \text { s/d selesai }\end{array}$ & $\begin{array}{l}\text { 1. Data : } \\
\text { - Klien merasa tidak berguna karena tidak dapat } \\
\text { membantu keluarga. } \\
\text { - Klien merasa minder karena penyakit yang di } \\
\quad \text { alaminya } \\
\text { - Klien sedih berada di yayasan }\end{array}$ & $\begin{array}{l}\text { S : } \\
\text { Senang } \\
\text { O : } \\
\text { Melatih kegiatan sesuai kemampuan yang } \\
\text { dipilih yaitu menyapu rumah } \\
\text { A : }\end{array}$ \\
\hline
\end{tabular}




\begin{tabular}{|l|l|l|}
\hline$\quad$ Klien merasa malu dalam menajlin asmara & Harga diri rendah (+) \\
$-\quad$ Klien tampak murung & $\mathrm{P}:$ \\
2. Diagnosa Keperawatan & Membantu Masak \\
$\quad$ Gangguan Konsep Diri : Harga Diri Rendah & - Menyuci piring \\
3. Tindakan Keperawatan & - Menyapu Halaman \\
Sp $4:$ Melatih kegiatan sesuai kemampuan yang dipilih 3 & \\
RTL : & \\
Follow up dan evaluasi SP 1-4 & \\
\hline
\end{tabular}




\section{BAB 4 \\ PEMBAHASAN}

Setelah mahasiswa melaksanakan asuhan keperawat kepada Ny. P dengan gangguan sensori persepsi: halusinasi pendengaran di Yayasan Pemenang Jiwa, maka penulis pada $\mathrm{BAB}$ ini akan membahasan kesenjangan antara teoritis dengan tinjauan kasus. Pembahasan dimulai melalui tahapan proses keperawatan yaitu pengkajian, diagnosa keparawatan, perencanaan, pelaksanaan dan evaluasi.

\subsection{Pengkajian}

Tahap pengkajian pada klien halusinasi dilakukan interaksi antara perawat klien melalui komunikasi terapeutik untuk mengumpulkan data dan informasi tentang status kesehatan klien. Selama pengkajian dilakukan pengumpulan data dari beberapa sumber, yaitu dari pasien dan pembina yayasan pemenang jiwa. Mahasiswa mendapat sedikit kesulitan dalam menyimpulkan data karena keluarga pasien jarang mengunjungi pasien di yayasan pemenang jiwa. Maka mahasiswa melakukan pendekatan kepada pasien melalui komunikasi terapeutik yang lebih terbuka membantu pasien untuk memecahkan perasaannya dan juga melakukan observasi kepada pasien. Adapun upaya tersebut yaitu:

a. Melakukan pendekatan dan membina hubungan saling percaya diri pada klien agar klien lebih terbuka dan lebih percaya dengan menggunakan perasaan.

b. Mengadakan pengkajian klien dengan wawancara

c. Mengadakan pengkajian dengan cara membaca status, melihat buku rawatan dan bertanya kepada pegawai ruangan sorik merapi (Chrisdayanti, 2019).

\subsection{Tahap Perencanaan}

Perencanaan dalam proses keperawatan lebih di kenal dengan asuhan keperawatan yang merupakan tahap selanjutnya setelah pengkajian dan penentuan diagnosa keperawatan. Pada tahap perencanaan mahasiswa menyusun rencana tindakan keperawatan Gangguan Persepsi Sensori : Halusinasi. Pada tahap ini antara tinjauan teroritis dan tinjauan kasus tidak 
ada kesenjangan sehingga mahasiswa dapat melaksanakan tindakan seoptimal mungkin di dukung dengan seringnya bimbingan dengan pembimbing. Secara teoritis digunakan secara strategi pertemuan sesuai dengan diagnosa keperawatan yang muncul saat pengkajian. Adapun upaya yang digunakan mahasiswa ialah :

a. Mengidentifikasi jenis halusinasi.

b. Mengidentifikasi isi halusinasi .

c. Mengidentifikasi waktu halusinasi.

d. Mengidentifikasi frekuensi halusinasi.

e. Mengidentifikasi situasi yang menyebabkan halusinasi.

f. Mengidentifikasi respon klien terhadap halusinasi.

g. Membantu pasien mempraktekkan latihan cara mengontrol halusinasi dengan menghardik.

h. Menjelaskan cara mengontrol Halusinasi dengan minum obat secara teratur.

i. Melatih pasien mengontrol halusinasi dengan bercakap - cakap dengan orang lain.

j. Melatih pasien mengontrol halusinasi dengan melakukan kegiatan terjadwal.

\subsection{Implementasi}

Pada tahap implementasi, penulis hanya mengatasi 2 masalah keperawatan yakni : diagnosa keperawatan halusinasi pendengaran dan harga diri rendah. Pada diagnosa keperawatan gangguan persepsi sensori halusinasi pendengaran dilakukan strategi pertemuan yaitu mengidentifikasi isi, frekuensi, waktu terjadi, perasaan, respon halusinasi. Kemudian strategi pertemuan yang dilakukan yaitu latihan mengontrol halusinasi dengan cara menghardik. Strategi pertemuan yang kedua yaitu anjurkan minum obat secara teratur, strategi pertemuan yang ke tiga yaitu latihan dengan cara bercakap-cakap pada saat aktivitas dan latihan strategi pertemuan ke empat yaitu melatih klien melakukan semua jadwal kegiatan. Pada diagnosa keperawatan harga diri rendah strategi pertemuan yang dilakukan yaitu 
mengidentifikasi kemampuan dan aspek positif yang masih dimiliki klien. Strategi pertemuan yang kedua yaitu membantu klien menilai kemampuan yang dapat digunakan. Strategi pertemuan yang ketiga yaitu membantu klien memilih/menetapkan kemampuan yang akan dilatih. Strategi pertemuan yang keempat yaitu latih kemampuan yang dipilih klien. Untuk melakukan implementsi pada keluarga, pada tahap-tahap diagnosa tidak dapat dilaksanakan karena penulis tidak pernah berjumpa dengan keluarga klien (keluarga tidak pernah berkunjung) (Gaol, 2021).

\subsection{Evaluasi Keperawatan}

Pada tinjauan teoritis evaluasi yang diharapkan adalah : Pasien mempercayai perawat sebagai terapis, pasien menyadari bahwa yang dialaminya tidak ada objeknya, dapat mengidentifikaasi halusinasi, dapat mengendalikan halusinasi melalui mengahrdik, latihan bercakap-cakap, melakukan aktivitas serta menggunakan obat secara teratur (Puspita, 2020). Pada tinjauan kasus evaluasi yang didapatkan adalah:

1. Klien mampu mengontrol dan mengidentifikasi Halusinasi.

2. Klien mampu mengontrol halusinasi dengan menghardik.

3. Klien mampu memahami penggunaan obat yang benar : 6 benar.

4. Klien mampu melakukan latihan bercakap-cakap dengan orang lain.

5. Klien mampu melaksanakan jadwal yang telah dibuat bersama. 


\section{BAB 5}

\section{PENUTUP}

\subsection{Kesimpulan}

Kesimpulan Berdasarkan uraian pada pembahasan di atas, maka penulis dapat disimpulkan bahwa:

1. Pengkajian dilakukan secara langsung pada klien dan juga dengan menjadikan status klien sebagai sumber informasi yang dapat mendukung data-data pengkajian. Pada kasus Ny. P, diperoleh bahwa klien mengalami gejala-gejala halusinasi seperti mendengar suara-suara, gelisah, sulit tidur, mondar-mandir, sedih, malu, menarik diri, dan lainlain. Diagnosa keperawatan yang muncul pada kasus Ny. P, Halusinasi pendengaran, isolasi sosial, harga diri rendah. Tetapi pada pelaksanaannya, penulis fokus pada masalah utama yaitu halusinasi pendengaran.

2. Perencanaan dan implementasi keperawatan disesuaikan dengan strategi pertemuan pada pasien halusinasi pendengaran dan harga diri.

3. Evaluasi diperoleh bahwa terjadi peningkatan kemampuan klien dalam mengendalikan halusinasi yang dialami serta dampak pada penurunan gejala halusinasi pendengaran yang dialami.

\subsection{Saran}

1. Bagi pasien hendaknya dapat mengontrol emosi dengan menerapkan strategi pelaksanaan, mengidentifikasi isi, frekuensi, waktu terjadi, perasaan, respon halusinasi, latihan mengontrol halusinasi dengan cara menghardik, manjurkan minum obat secara teratur, latihan dengan cara bercakap-cakap pada saat aktivitas dan melatih klien melakukan semua jadwal kegiatan.

2. Bagi Yayasan Pemenang Jiwa hendaknya memberikan pelayanan kesehatan yang baik dan membuat suasana lingkungan menjadi lebih nyaman agar klien tidak melakukan risiko perilaku kekerasan. Usahakan memberikan saran, nasehat dan motivasi kepada klien agar klien mendapatkan cara tentang bagaimana mengontrol marah. 


\section{DAFTAR PUSTAKA}

Aldam, S. F. S., \& Wardani, I. Y. (2019). Efektifitas penerapan standar asuhan keperawatan jiwa generalis pada pasien skizofrenia dalam menurunkan gejala halusinasi. Jurnal Keperawatan Jiwa,7(2), 165-172. https://doi.org/10.26714/jkj.7.2.2019.167-174

Caturini, E., \& Handayani, S. (2014). Pengaruh Cognitive Behavioral Therapy (CBT) terhadap Perubahan Kecemasan, Mekanisme Koping, Harga Diri pada Pasien Gangguan Jiwa dengan Skizofrenia di RSJD Surakarta. Interest: Jurnal Ilmu Kesehatan, 3(1). http://jurnal.poltekkessolo.ac.id/index.php/Int/article/view/80

Chrisdayanti, M. (2019). Asuhan Keperawatan Jiwa Pada Klien Halusinasi Pendengaran Terintegrasi Dengan Keluarga Di Wilayah Kerja Puskesmas Lempake Samarinda. Karya Tulis Ilmiah. Politeknik Kesehatan Kementerian Kesehatan http://repository.poltekkes-kaltim.ac.id/411/

Gaol, H. L. (2021). Asuhan Keperawatan Jiwa Pada Ny. I Dengan Masalah Halusinasi Pendengaran. Web. https://doi.org/10.31219/osf.io/r5anf

Hidayah, A. N. (2015). Pengaruh Terapi Aktivitas Kelompok Stimulasi PersepsiSensori Terhadap Kemampuan Mengontrol Halusinasi Pada Pasien Halusinasi di RSJD dr. Amino Gondohutomo Semarang. FIKkeS, 8(1). https://jurnal.unimus.ac.id/index.php/FIKkeS/article/view/1900

Halawa, A. (2015). Pengaruh Terapi Aktivitas Kelompok: Stimulasi Persepsi Sesi 1-2 Terhadap Kemampuan Mengontrol Halusinasi Pendengaran Pada Pasien skizofrenia Di Ruang Flamboyan Rumah Sakit Jiwamenur Surabaya. Jurnal Keperawatan, 4(1), 30-37. https://doi.org/10.47560/kep.v4i1.185

Kementerian Kesehatan RI. (2019). Situasi Kesehatan Jiwa Indonesia. https://pusdatin.kemkes.go.id/download.php?file=download/pusdatin/infod atin/InfoDatin-Kesehatan-Jiwa.pdf

Mislika, M. (2021). Penerapan Asuhan Keperawatan Jiwa Pada Ny. N Dengan Halusinasi Pendengaran. Web. https://doi.org/10.31219/osf.io/efw6j

Muhith. A. (2015). Pendidikan Keperawatan Jiwa. Yogyakarta : CV Andi Offest.

Ningsih, P., Murtiani, M., \& Ilyas, M. (2013). Pengaruh Terapi Aktivitas Kelompok Stimulasi Persepsi Terhadap Kemampuan Mengontrol Halusinasi Pada Pasien Halusinasi Di Ruang Kenanga Rumah Sakit Khusus Daerah Propinsi Sulawesi Selatan. Jurnal Ilmiah Kesehatan Diagnosis, 2(4), 28-34. http://ejournal.stikesnh.ac.id/index.php/jikd/article/view/440 
Oktiviani, D. P. (2020). Asuhan Keperawatan Jiwa Pada Tn. K dengan masalah Gangguan Persepsi Sensori: Halusinasi Pendengaran di Ruang Rokan Rumah Sakit Jiwa Tampan (Doctoral dissertation, Poltekkes Kemenkes Riau). http://repository.pkr.ac.id/id/eprint/498

Pardede, J. A., Keliat, B. A., \& Yulia, I. (2015). Kepatuhan dan Komitmen Klien Skizofrenia Meningkat Setelah Diberikan Acceptance And Commitment Therapy dan Pendidikan Kesehatan Kepatuhan Minum Obat. Jurnal Keperawatan Indonesia, 18(3), 157-166. http://dx.doi.org/10.7454/jki.v18i3.419

Pardede, J. A., \& Laia, B. (2020). Decreasing Symptoms of Risk of Violent Behavior in Schizophrenia Patients Through Group Activity Therapy. Jurnal Ilmu Keperawatan Jiwa,3(3), 291-300. http://dx.doi.org/10.32584/jikj.v3i3.621

Pardede, J. A., Silitonga, E., \& Laia, G. E. H. (2020). The Effects of Cognitive Therapy on Changes in Symptoms of Hallucinations in Schizophrenic Patients. Indian Journal of Public Health Research \& Development, 11(10). https://doi.org/10.37506/ijphrd.v11i10.11153

Pardede, J. A., \& Siregar, R. A. (2016). Pendidikan Kesehatan Kepatuhan Minum Obat Terhadap Perubahan Gejala Halusinasi Pada Klienskizofrenia. Mental

Health, 3(1).https://www.academia.edu/29589194/Pendidikan_Kesehatan Kepatuhan_Minum_Obat_Terhadap_Perubahan_Gejala_Halusinasi_Pada Pasien_Skizofrenia

Puspita, I. A., Annisa, F., Sulistyowati, A., \& Diana, M. (2020). Asuhan Keperawatan Jiwa Pada Tn. S Dengan Masalah Utama Halusinasi Pendengaran Dengan Diagnosa Medis Skizofrenia Di Ruang Gelatik Rumah Sakit Jiwa Menur Surabaya. (Doctoral dissertation, Akademi $\begin{array}{llll}\text { Keperawatan Kerta } & \text { Cendekia }\end{array}$ http://eprints.kertacendekia.ac.id/id/eprint/219/

Putri, V. S. (2017). Pengaruh terapi aktivitas kelompok stimulasi persepsi halusinasi terhadap kemampuan mengontrol halusinasi pada pasien skizofrenia di ruang rawat inap arjuna rumah Sakit Jiwa Daerah Provinsi Jambi. Riset Informasi Kesehatan, 6(2), 174-183. https://doi.org/10.30644/rik.v6i2.95

Ramdani, M. W., \& Ismahmudi, R. (2016). Asuhan Keperawatan pada Bapak B yang Mengalami Halusinasi di Ruang Elang Rumah Sakit Jiwa Daerah Atma Husada Mahakam Samarinda. Karya Tulis Ilmiah. Sekolah Tingg Ilmu Kesehatan Muhammadiyah. https://dspace.umkt.ac.id/handle/463.2017/1075 
Riskesdas. (2018). Profil Kesehatan : Kesehatan Jiwa Indonesia. https://kesmas.kemkes.go.id/assets/upload/dir_519d41d8cd98f00/files/Has il-riskesdas-2018_1274.pdf

Rossyda. E. N. (2019). Penerapan Cognitive Behaviour Therapy (Cbt) Pada Pasien Halusinasi Pendengaran Di Wisma Shinta Rsj. Prof Dr. Soerojo Magelang. (Ners dissertation, Poltekkes Semarang). http://repository.poltekkes-smg.ac.id/?p=show_detail\&id=18163

Sejati, A. M. W. (2017). Efektivitas Pemberian Mozart "Sonata K. 331" Terhadap Pengurangan Halusinasi Pendengaran Pada Penderita Skizofrenia. (Doctoral Dissertation, Universitas Negeri Semarang). http://lib.unnes.ac.id/28393/

Setiawan, R. I. (2017). Asuhan Keperawatan Pada Klien Skizofrenia Simplek Dengan Masalah Keperawatan Gangguan Persepsi Sensori "Halusinasi Pendengaran" Di Ruang Flamboyan Rumah Sakit Jiwa Menur Surabaya (Doctoral dissertation, STIKes Insan Cendekia Medika Jombang). http://repo.stikesicme-jbg.ac.id/224/

Sepalanita, W., \& Khairani, W. (2019). Pengaruh Terapi Aktivitas Kelompok dengan Stimulasi Persepsi terhadap Kemampuan Mengontrol Halusinasi pada Pasien Skizofrenia. Jurnal Ilmiah Universitas Batanghari Jambi, 19(2), 426-431. http://dx.doi.org/10.33087/jiubj.v19i2.690

Sumartyawati, N. M. (2019). Efektivitas Terapi Aktivitas Kelompok Stimulasi Persepsi Dan Terapi Religius Terhadap Frekuensi Halusinasi. PrimA: Jurnal Ilmiah Ilmu Kesehatan, 5(1). http://dx.doi.org/10.47506/jpri.v5i1.134

Susilaningsih, I., Nisa, A. A., \& Astia, N. K. (2019). Penerapan Strategi Pelaksanaan: Teknik Menghardik Pada Ny. T Dengan Masalah Halusinasi Pendengaran. Jurnal Keperawatan Karya Bhakti,5(2), 1-6. http://ejournal.akperkbn.ac.id/index.php/jkkb/article/view/28

Sutinah, S., Harkomah, I., \& Saswati, N. (2020). Terapi Aktivitas Kelompok Stimulasi Persepsi Sensori (Halusinasi) Pada Klien Halusinasi Di Rumah Sakit Jiwa Provinsi Jambi. Jurnal Pengabdian Masyarakat Dalam Kesehatan, 2(2). http://dx.doi.org/10.20473/jpmk.v2i2.19972

Waode Mu'rifah Razak, P., \& Rini, D. S. (2018). Asuhan Keperawatan Pada Pasien Ny. N Dengan Skizofrenia Di Ruang Delima Rumah Sakit Jiwa Provinsi Sulawesi Tengggara (Doctoral dissertation, Poltekkes Kemenkes Kendari). http://repository.poltekkes-kdi.ac.id/660/

Wulandari, T. (2018). Pengaruh Pendidikan Kesehatan Terhadap Perubahan Tingkat Kemampuan Keluarga Dalam Perawatan Halusinasi Di Wilayah Kerja Puskesmas Geger Kabupaten Madiun. Thesis. Program Studi 
Keperawatan Stikes Bhakti Husada Mulia Madiun. http://repository.stikesbhm.ac.id/282/

Zelika, A. A., \& Dermawan, D. (2015). Kajian Asuhan Keperawatan Jiwa Halusinasi Pendengaran Pada Sdr. D Di Ruang Nakula RSJD Surakarta. Profesi (Profesional Islam): Media Publikasi Penelitian, 12(02). http://dx.doi.org/10.26576/profesi.87 